\title{
Strengthening the Organization of the Aliansi Indonesia Damai in Internalizing Peace Values
}

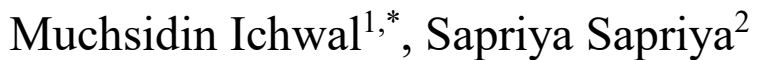

\author{
1,2 Universitas Pendidikan Indonesia, Bandung, Indoesia \\ *Corresponding author. Email: muchsidinichwal@upi.edu
}

\begin{abstract}
The values of peace in society face challenges with the existence of various cases of radicalism and terrorism in society, this is because there are people who want the community to be in a state of conflict and the spread of teachings that are misused for the benefit of the group. This study used a qualitative approach with a case study method, where the research was conducted at Aliansi Indonesia Damai because it has a program to internalize the values of peace in society by presenting former terrorists and terrorist victims, data collection techniques use interviews, observation and documentation, and data analysis using reduction, presentation and conclusion. The results showed that the implementation of the Aliansi Indonesia Damai program used a humanist approach in the form of cognitive delivery of deviant teachings in society and how to counter them. Actors who are involved in efforts to internalize the values of peace, namely inviting elements of former terrorism, victims of terrorism and universities to convey to the public about the dangers, impacts and solutions of acts of radicalism and terrorism. The conclusion in this study shows that the peaceful Indonesian alliance organization uses a humanist approach by bringing together former terrorists, terrorist victims and universities to internalize the values of peace.
\end{abstract}

Keywords: Aliansi Indonesia Damai Organization, The Values of Peace, Society.

\section{INTRODUCTION}

In various parts of the world, peace is the dream of all nations. In the global system, the United Nations (UN) has set peace as one of the universal priorities for the transformation of the modern world with the desire to foster an environment that is peaceful, equal, just, free from terror and conflict in 17 Sustainable Development. Without integration there is no sustainable growth and without sustainable development there is no peace. This is a very important question, provided that for different reasons, disputes between countries and conflicts within one country that affect the population, in different countries, never go away.

Based on this, Umar [1] notes that "the United Nations wishes to convey that world change cannot be realized without a peaceful culture and there needs to be initiatives that promote life-saving peace in a diverse and heterogeneous global society".

Hillman and Baydoun [2] note that "there are more and more questions that can break national solidarity, from attempts to disrupt the order of existence with issues of caste, race and class, to conflicts between religious classes. In addition, the social resilience of society needs to be interpreted as state wealth and not a justification for division. This is of course a problem for Indonesia's complex culture, ethnically, racially, historically and religiously as a whole. Idi [3] states that "the heterogeneity of society needs to be interpreted as the wealth of the Indonesian nation in building a harmonious social life."
This view implies that the complexity of Indonesian society is one of the advantages of the Indonesian nation.

The term that stands out in this period is not terrorism but armed movement and security disturbances. The problems faced are ideological and separatist in nature with the basic motivation that drives them is ideologicalpolitical as well. Apart from political movements with ideological nuances, it was also marked by movements with regional nuances, namely the Pemerintahan Revolusioner Republik Indonesia (PRRI) and Perjuangan Semesta or Perjuangan Rakyat Semesta (Permesta) rebellions as separatist movements that wanted separation of regions. Judging from the scale of the movement's target, this period was included in the national category, namely movements aimed at parties existing in a territory and national State power, in the form of armed rebellion, disruption of national stability, and disturbances of national security [4].

Viewed from the citizenship perspective from the civic knowledge element, knowledge about citizenship is still weak, of course this is related to education, especially in relation to the relationship between the state and citizens, for example democracy, the rule of law, the enforcement of human rights [5]. Devotion in life together, especially those related to commitment as a nation in state life, acceptance between one group and another or the problem of nationalism has not been supported by adequate civic skills (such as critical thinking skills, skills in democracy, and skills in realizing it. a sense of nationalism). 
Elgenius, Gabriella, and Jens Rydgren [6] stated that national life in this period was still marked by strong ethno-nationalism, exclusivism, so that the movements that occurred at that time had ideological-religious and regional nuances. Judging from the civic virtue, which should be the spirit of tolerance, nationalism / unity, civilization, and justice colors the life of the nation and state, but in reality, national life shows the strong spirit of the group both from the side of ethnicity, religion and group politics. In such a spirit intolerance and distrust can occur. If that happens, it is a significant thing to influence someone to be suspicious, to act radically and to trigger acts of terrorism.

Based on this, it shows that radicalism and terrorism already existed in Indonesia during the independence era. In this condition, preventive efforts have been made with the BNPT National Policy as the leading sector which is given the authority to formulate policies and strategies and to coordinate the countermeasures of terrorism, Aisy et al. [7] has three strategies, namely securing and deradicalizing prevention, prosecution and capacity building and foreign cooperation. In carrying out its policies and plans, BNPT follows a strategy from upstream to downstream. Not only is law enforcement and implementation (hard power) carried out to solve crimes, but the most important thing is to fix the problem of prevention (soft power). This reveals that the BNPT has a vigilant and repressive policy to address issues of radicalism and extremism.

In its implementation, BNPT needs assistance from community organizations to further optimize the strengthening of the values of peace in society. This was done as an effort to prevent the spread of radicalism and terrorism ideas in society.

\section{THEORETICAL REVIEW}

\subsection{The Values of Peace}

Peace is not only a physical condition, but also a mental condition. Oxford Learner's Dictionary Peace is characterized as a condition free from strife, conflict, aggression and concern [8]. The existence of justice, law and order, in short, the existence of democracy, is not just a lack of war, according to Malik [9]. Moreover, there are some who claim that harmony is a disadvantageous situation. Optimism is what we want and like, but pessimistic words are what we don't want.

The term peace is described in the large Indonesian dictionary as an environment that is not full of violence, war free, conflict free, and builds peace [10]. In comparison, the term peace relates to various aspects of life, such as home, culture, country and state. Whereas the term peace is a noun form from the root word 'peace' plus the prefix 'per' and the suffix 'an.' By adding to this appeal, the term peace becomes a word that contains a component of injustice that makes peace, is not hostile or aggressive, and so on, and so on [11].

Peace research has questioned traditional perceptions of peace over the past few years and claims that peace is not as easy as reducing conflict and eliminating aggression. Academics have all decided that if humans want to transition to a more stable society, humans need a complete vision of peace [12].

Regarding peace, Asnawi and Safruddin also reported giving two concepts of peace, namely [13]: peace is the cessation or reduction of aggression in all forms and peace is a shift from innovative non-violent confrontation.

Hendry said peace was directed not only to defuse conflict, but also to try to prevent violence. Furthermore, the notion of peace has been divided into three different forms: (i) Constructive Peace Principle (striving to resolve issues at the center of conflict); (ii) Negative Peace definition (only to end the aggression that exists in the conflict) [14]. So, when the pessimistic notion of harmony is at work, the strife is over and the risk of conflict remains the umpteenth time. The principle of positive stability, meanwhile, is aimed at avoiding the re-emergence of conflict, and even if these disputes resurface, peace policies will soon be put into effect. Because peace is not limited to the absence or reduction of violence but also the internal mental state, a sense of stability, peace, tranquility and anxiety that does not occur in an entity or group, it is expressed in his thoughts and attitudes [15].

\subsection{Indicators of the Values of Peace}

The construction of peace is how a plural society can build a community group that is able to eliminate conflict in a non-violent manner so as to create peace and tranquility within the community itself. Based on the theory of peace culture launched by UNESCO that a culture of peace can occur if there are indicators of a culture of peace in a society, namely [16] namely respect all life; reject violence; share with others; listen to understand; preserve the planet; rediscover solidarity; equality between men and women; and democracy.

An explanation of the indicators obtained from the assessment of the culture of peace will be presented as follows:

1. One of the pillars in creating peace is acceptance of differences. Acceptance of differences is accepting that other people also have both opinions, ideals, hopes and desires that may differ [17]. The treatment of difference also includes the acceptance that other people have different religious, ethnic, racial backgrounds so that there is no reason to act in a discriminatory manner.

2. Understand other people's personal perceptions and be comfortable with those perceptions. Understanding other people's personal perceptions means knowing how they perceive the world and interpret everything that is received [18]. Be sensitive. In a sense it can neutralize and deal with the subjective feelings that flow. Move gently without giving judgment in the belief that other people have a unique awareness.

3. Solidarity can be defined as a unity of interests, togetherness, sympathy [19]. In this case, it has a sense of solidarity, which is binding to one another in social relationships. As there is a sense of kinship. Besides that, there is also a sense of solidarity that exists in the 
people of the Arab village, social activities such as the existence of rukun and rewangrewang can lead to high emotional relationships.

4. The first form of a culture of peace, namely respect all life, will create a good relationship. Such as generating mutual trust [20]. Because trust is the basis for forming relationships between ethnicities, and raising prejudice against other ethnicities and each ethnicity can develop their potential. So that this is where the willingness to share (share with other) will be created.

5. Peace can be created when environmental sustainability and beauty are well preserved [21]. Environmental sustainability can be created when all components of the Arab village community have an ecological attitude.

6. This form of peaceful culture teaches that every human being has the right to get his rights as a human being [22]. With the existence of equality between men and women, it is hoped that there will be no subordination, standardization of roles, double burdens, marginalization and violence against women and men.

\subsection{Radicalism and Terrorism}

The word radicalism is found in the Indonesian dictionary, an uptake consisting of the following two terms radical and ism, which implies an understanding or area defined by aggression or dramatic social and political reforms or transitions or reforms. The Indonesian Encyclopedia states in his book that radicalism is a political current whose students are looking for drastic results, at least one that is further away from the manifestation of its ideology. In essence, both meanings call for severe, aggressive and dramatic change [23]. In comparison, fundamentalism, fanaticism, exclusivity, bigotry and militancy can be attributed to fundamentalists [24].

Bhorat, et.al [25] said that radicalism is a radical that develops democratically, collective strength and fear will usually become permanent radicals. The factors that make a person become radical and a radical follower depend on the environmental factors that support him. Morris and Mueller [26] state that radical group movements are focused on reciprocal attributes, real or imaginary perceptions and experiences and collectivity experiences, in comparisons or comparisons with one or more actual or imagined classes.

The habit of radicalism is suspected by a group or other individual as a radical group, whether one group or a person is labeled as an individual or group with opinions that are considered radical, there is no simple standard. Until recently, the media or the power of democracy often determined.

Moreover, the importance of radicalism is not a social consequence of any ideology. Mage [27], because emotionally and irrationally divisive and often deify lust, expresses his own desires and does not respect the point of view of others, regardless of positive or bad beliefs.
In the New World Dictionary Terrorism, Webster emphasizes political motive when the term itself applies to violence, the use of force, or attempts to demoralize, threaten or specially to use weapons or political policies. terrorist acts terrorize [28].

Terrorism has a distinctive classification that is almost similar to other offenses, and only the intent and motive for certain activities are different. According to the U.S. Army's Strategic and Preparation Command [29], a particular movement generally uses various reasons as an excuse for terrorism.

Terrorism activities and motives vary. There are many forms of terrorism. Traditional and general acts of terrorism are divided into attacks: threats, incendies, vandalism, explosions, kidnappings, captives, looting, raids, assassinations, assassinations and weapons, as modified by the United States military terror guides and Theory Command. Incandescent, sabotage, bombing, kidnapping, hostage-taking, conquest, astonishing assault, murder and weapons of mass destruction [30].

\section{METHODS}

This study uses a qualitative approach to generalize research findings. The characteristics of the research sample were taken from three different aspects to prevent informant bias, the characteristics of this sample consisted of the Aliansi Indonesia Damai as the implementer of activities that had programs related to efforts to create peace in Indonesia, the characteristics of the community were those who received responses from activities carried out by The Aliansi Indonesia Damai, while the expert is the party who understands the problems related to peace in society from an academic point of view, so that the three informants are in accordance with the research. These three sources are a source of research because they are subjects involved in activities to prevent terrorism and radicalism in society.

Nazir [31] the data collection method is a data processing strategy or method that may be used by researchers. There are many data collection methods that researchers usually use. Researchers can use an established system or mix according to the problem [32]. The research method uses interviews, observation and documentation. In this study, the data processing stage will continue from the beginning to the end of the research both at home and abroad. Simultaneously with the data collection process, data analysis was carried out. Data deletion, data presentation and drawing conclusions / checks, among others. All three processes existed in the same period.

\section{RESULTS AND DISCUSSION}

\subsection{Problems of Radicalism and Terrorism in Society}

Based on the results of the study, it shows that acts of radicalism and terrorism in Indonesia are due to a lack of public understanding of nationalism and tolerance. Based 
on interviews, research shows that acts of terrorism committed on the basis of religion may be the right thing. This condition indicates that the values of tolerance are starting to conform in society. The results of the interview also show that people interpret nationalism and partiotism as a physical struggle against the invaders, thus making people not understand the essence of nationalism and patriotism.

Based on the results of this study, it shows that the spirit of nationalism and patriotism among young people is one of the main problems faced by a country in its progress towards a higher civilization. Many youths are disoriented and involved in self-interest as a result of the recent decline in nationalism and patriotism. Education often only relies on cognitive aspects, while mental aspects are not given adequate consideration and are not part of knowledge. Education is often the center of attention.

Another problem that arises in cultivating an attitude of nationalism in education was conveyed by Maftuh [33] who stated that there are five challenges for the Indonesian people in cultivating an attitude of nationalism. It seems that the precepts of Pancasila are still not grounded, so that Indonesian citizens have not been implemented properly. The life of the Indonesian people, especially the younger generation in the era of globalization, has a strong enough influence on external cultural values, so that many attitudes and actions have begun to emerge and are still not widely applied both at the level of community life and at the level of community life. level of community life. at the level of community life. Pancasila seems to be just a warning. Not in line with the values of Pancasila, some residents, especially among the younger generation, think that national values are currently experiencing a decline.

Understanding of religion that does not consider Indonesian nationalism and the nation-state as well as the value of universalism. Supporters of this understanding often oppose democracy as a successful governance structure, and in the end they do not see Pancasila as a necessary and appropriate philosophy for the Indonesian state. This understanding is established not only in society but also in school students and the function of education both formal and non-formal education in incorporating Pancasila values, including national values for the Indonesian nation, especially the younger generation, still needs to be questioned.

Empirically, the birth of extremism is accused of being radicalism. With the increasing number of incidents of terrorism in Indonesia, terrorism is an extraordinary crime. This can be seen from the series of suicide bombings that occurred in Surabaya in three stages. Ironically, this is done by families involving children. Not only one day later, on May 14, 2018, the Surabaya Police detonated a suicide bombing. Once again, all family members, including minors, joined in the action. Fortunately, one of the bomber's daughters was rescued.
Any suicide attack can be understood as widespread and harassing radicalism that contributes to acts of terrorism. The birth of radicalism itself is marked by, among other things, the birth of religious groups that also use aggressive methods in carrying out their da'wah. There are many styles, variations and orientations of radical Islamic organizations. However, conservative Islamic groups, namely the use of harassment, have something in common. Various parties reacted to the rise of extreme Islamic ideology [34]. Some responded positively by helping themselves, some offered a reactive emotional response, some reacted creatively, and some reacted anarchically.

Theoretically, there are four paths to study social problems in the theory of relative deprivation. There are two variables (A and $\mathrm{B}$ ) and one object $(\mathrm{X})$. Next, vector A knows that it does not have $\mathrm{X}$. So A realizes that there is an additional variable (B) for X. Since A knows that all its drawbacks are that it does not have X, then A needs X. After $\mathrm{A}$ is sure that $\mathrm{X}$ wants to correct the weakness, seize A practical. This action shows a permissive attitude towards the actions taken by someone to seize power in radical ways.

\subsection{Strengthening the Values of Peace by the Aliansi Indonesia Damai}

Based on research data, it shows that the Aliansi Indonesia Damai (AIDA) was established to create a more peaceful Indonesia through the role of victims and former perpetrators of terrorism. AIDA has a vision of Building a peaceful Indonesia based on the values of mutual respect, mutual trust and brotherhood.

Likewise, AIDA has a mission to empower, train and encourage victims of terrorism to become ambassadors for peace by making the public aware of the negative effects of violence so that everyone refrains from using acts of violence in pursuing a goal and encouraging, promoting and facilitating the forging of relationships between victims and former perpetrators. acts of terrorism to create a strong and united voice for peace.

In an effort to strengthen peaceful values, AIDA has a number of programs, in the form of:

1. Empowerment and Assistance Program

a) Mental Support

b) Victim Right Advocacy

c) Educational Aid and Achievement Scholarships

d) Terrorism Action Warning

2. School Program

a) Peace Campaign

b) Peace Team Training

c) Teacher training

3. Communication Program

a) Religious Leadership Training

b) Journalist Training

c) The "Voice of Peace" Newsletter

d) Short Filmmaking

e) Victim Catalog Writing

4. Prison Program 
a) Prison Officer Training

b) Prison Assisted Citizens Intervention Program

The efforts made by AIDA also collect aspirations from various regions in Indonesia to voice peaceful actions. This can be seen from one of the articles on the AIDA official website, which explains the Bugis philosophy for national peace which states that humanizing humans is internalized by the Bugis community in a trilogy of wisdom known as sipakatau, sipakaingeq and sipakalebbi.

Sipakatau means to humanize each other in any condition. Sipakatau is shown by respecting each other, being polite, and not discriminating against others even though there are various ethnicities, religions, races, and groups.

Sipakatau is considered to carry the spirit of equality as well as anti-discrimination in life. Indirectly, or glorify peace in people's lives, because discrimination is a threat to peace, it often leads to acts of violence by individuals or groups.

Sipakaingeq means to remind each other. This philosophy is an acknowledgment of the Bugis society for the shortcomings of each human being. Sipakaingeq is shown by advising each other or reprimanding each other for making mistakes. His spirit is to represent social control in order to protect the immediate environment from behavior that is less praiseworthy.

Citing field theory, behavior is the result of absorbing information about what we pay attention to from the environment and the support provided by the environment. So sipakaingeq is the effort of the Bugis people to protect each other to get used to the good things in their environment [35]. Efforts to protect every citizen is an important aspect in strengthening national solidarity, it is an action taken by AIDA as an organization that is committed to implementing the values of peace.

\subsection{Implementation Methods of Strengthening the Values of Peace}

The success of AIDA in minimizing radicalism and terrorist activities in the community is due to the high culture of peace that is pursued by the peaceful Indonesian alliance organization. Every society who has different beliefs can respect and appreciate one another, so that every community care about one another.

The implementation of strengthening peaceful values carried out by AIDA is carried out by three aspects that play an important role in providing understanding to the community about a culture of peace which aims to prevent radicalism and terrorism notions from entering the community. These three aspects include religious leaders, academics and terrorists.

These three aspects of the community have different duties and functions. From the element of religious figures, the role of religious leaders has a very strategic influence in providing knowledge about religion for the community.
The form of activities carried out by AIDA through three approaches, namely scientific, welfare and professional approaches. This is seen as an effective way to prevent the notion of radicalism from entering the community because if you use a legal approach, it is considered less humane and tends to be indoctrinating, it is necessary to take another approach, such as a welfare approach so that people can focus more on understanding statehood. well. So, it can be concluded that the approach taken by AIDA as an effort to strengthen the values of peace in society, is not only carried out through scientific methods from a religious or state perspective, but touches on the realm of social welfare and community professional development.

The welfare approach in the process of strengthening the values of peace carried out by AIDA is very strategic, because by itself people will not think about radicalism and focus on developing their abilities. In addition to the welfare approach, AIDA can conduct early detection of radical movements, either through a top-down process carried out by outsiders, or those carried out from the bottom up, namely the individual himself explores radicalism through various sources so that he is infiltrated.

In the scientific aspect, AIDA plays an important role in the process of strengthening the values of peace or it can be said to be the spearhead of these activities, because the learning is thorough to all aspects of society, the learning carried out by AIDA has many aspects such as religious, state, political and legal aspects that aim to to form a society that has awareness of the life of the nation and state.

This indirectly creates a culture of peace in the community in eliminating radicalism and terrorism, Muchith [36] states that not all forms of radicalism are acts of violence, but can also be manifested in the form of words and attitudes that have the potential to produce violence. not in accordance with educational norms. Attitudes that have the potential to give birth to violence have implications for the emergence of situations and conditions in the community that are not pleasant for everyone to carry out their daily activities.

Forming a culture of peace in the community is the implementation of deradicalization activities carried out by various elements in the community and the support of a peaceful Indonesian organization which is the driving force in creating a culture of peace in society. All elements in society are correlated with one another, so that it can create a culture of peace in the community.

Minimizing radicalism by strengthening the organization shows aspects of strengthening humanism in society, because it does not directly carry out repressive actions with various legal instruments [37].

This scientific activity is very important because in the learning process it will change society in terms of cognitive, affective and psychomotor. So that there will 
be changes in people's behavior according to what is stated in Pancasila and the 1945 Constitution.

\section{CONCLUSION}

The problem of terrorism and radicalism in society needs to be prevented so that the Indonesian nationality is maintained. The effort made by AIDA is by strengthening the values of peace in society with a program that invites former terrorism and terrorism victims to give views to the community. AIDA also collaborates with religious leaders and academics to help the AIDA program succeed, so that in organizational activities various elements of society take part in efforts to strengthen the values of peace in society.

\section{REFERENCES}

[1] M. Umar, "Internalisasi Nilai Kedamaian melalui Pendidikan Kedamaian sebagai Penguatan Pembangunan Karakter pada Masyarakat Heterogen." Waskita: Jurnal Pendidikan Nilai dan Pembangunan Karakter 1, no. 1 (2017): 77-98.

[2] J.R. Hillman, and E. Baydoun. "Review of the Roles of Governments and Universities and Their Interrelationships: An Urgent Need for Governance Reform in the Arab World." In Higher Education in the Arab World, pp. 1-79. Springer, Cham, 2020.

[3] A. Idi, Konflik etno religius di Asia Tenggara. Lkis Pelangi Aksara, 2018.

[4] Y.H. Nurasarastriya, Radikalisme dan Terorisme di Indonesia dari Masa ke Masa (Tinjauan dari Perspektif Kewarganegaraan). PAX HUMANA, 2, no. 2, (2015): 189-204.

[5] R.T. Knowles, T.P. Judith, and C. Barber. "Enhancing citizenship learning with international comparative research: Analyses of IEA civic education datasets." Citizenship Teaching \& Learning 13, no. 1 (2018): 7.

[6] G. Elgenius, and J. Rydgren. "Frames of nostalgia and belonging: The resurgence of ethno-nationalism in Sweden." European Societies 21, no. 4 (2019): 583-602.

[7] B.R. Aisy, D.O. Ibrahim, K.K.H. Intang, and M.A. Tindage. "Penegakan Kontra Radikalisasi melalui Media Sosial oleh Pemerintah dalam Menangkal Radikalisme." Jurnal Hukum Magnum Opus 2, no. 1 (2019): 276592.

[8] C.Y. Untalan, "Decentering the self, seeing like the other: toward a postcolonial approach to ontological security." International Political Sociology 14, no. 1 (2020): 40-56.

[9] Malik, (ed.), Modul Resolusi Konflik Agama dan Etnis di Indonesia. Jakarta: Pusat Bahasa dan Budaya UIN Syarif Hidayatullah Jakarta, 2004.

[10] K. Labobar, "The Advantage of Peace Theology towards Exclusive, Inclusive, and Pluralist Theology for Realizing Religious Community in Indonesia." The International Journal of Social Sciences World (TIJOSSW) 2, no. 2 (2020): 122143.

[11] W.J.S. Poerwadarminta, Kamus Umum bahasa Indonesia diolah oleh Pusat Pembinaan dan Pengembangan bahasa Departeman Pendidikan dan Kebudayaan. Jakarta: Balai Pustaka, 1991.

[12] M. Jamil, Tradisi Ikhtilaf dan Budaya Damai di Pesantren. Semarang: Litbang, 2012.
[13] Asnawi dan Safruddin, Studi Perdamaian: Perdamaian dan Konflik Pembangunan dan Peradaban. Surabaya: Pustaka Eureka, 2003.

[14] E. Hendry Ar, Sosiologi Konflik. Pontianak: STAIN Pontianak Press, 2009.

[15] M.D.A. Malek, "Mental Health and Social Work: The Islamic Perspectives." Mental Health and Social Work (2020): 395-413.

[16] M. Mukhafidoh, Analisis Konstruksi Budaya Damai di Kampung Arab. [online]. Diakses dari http://eprints.walisongo.ac.id/6997/5/BAB\%20IV.p df, 2016.

[17] Psaltis, Charis, H. Cakal, N. Loizides, and I.K. Bonnenfant. "Internally displaced persons and the Cyprus peace process." International Political Science Review 41, no. 1 (2020): 138-154.

[18] M.P Boyle, "Personal perceptions and perceived public opinion about stuttering in the United States: Implications for anti-stigma campaigns." American Journal of Speech-Language Pathology 26, no. 3 (2017): 921-938.

[19] M. Stewart, and U. Schultze. "Producing solidarity in social media activism: The case of My Stealthy Freedom." Information and organization 29, no. 3 (2019): 100251.

[20] M. Idris, E. Willya, I.S. Wekke, and S. Mokodenseho. "Peace Resolution in Education and Application on Information and Communication Technologhy." International Journal of Advanced Science and Technology 29, no. 6 (2020): 33493358 .

[21] L. Agirreazkuenaga, "Education for Agenda 2030: What Direction do We Want to Take Going Forward?." Sustainability 12, no. 5 (2020): 2035.

[22] G. Tuncel, "Improving the Cultural Responsiveness of Prospective Social Studies Teachers: An Action Research." Educational Sciences: Theory and Practice 17, no. 4 (2017): 1317-1344.

[23] R.I. Mage, "Prospek Gerakan Radikalisme di Indonesia". Jurnal Populis, 2(3), 2017, 237-252.

[24] W. Setiawan, Pola Keberagamaan Mahasiswa Sekolah Tinggi Agama Islam Negeri Jurai Siwo Metro Lampung. Jurnal Multikultural \& Multireligius, 11 (4), 2012, 34-45.

[25] H. Bhorat, M. Buthelezi, I. Chipkin, S. Duma, L. Mondi, C. Peter, M. Qobo, M. Swilling, and $\mathrm{H}$. Friedenstein. "Betrayal of the promise: how South Africa is being stolen." State Capacity Research Project (2017): 1-72.

[26] D.A. Morris, \& C.M. Mueller, Frontiers in Social Movement Theory. New Haven: Yale University Press, 1992.

[27] Op.,cit, Mage (2017).

[28] H.C. Black. (1990). Black's Law Dictionary 6th Edition, West Publishing,St. Paul-Minn.

[29] US Army TRADOC. (2007). Military Guide to Terrorism, US TRADOC, Kansas.

[30] L. Hahn, R. Tamborini, E. Novotny, C. Grall, and B. Klebig. "Applying moral foundations theory to identify terrorist group motivations." Political Psychology 40, no. 3 (2019): 507-522.

[31] M. Nazir (2011). Metode Penelitian. Bogor: Ghalia Indonesia.

[32] R. Kriyantono, (2009). Teknik Praktis Riset Komunikasi. Malang: Prenada Media Group.

[33] B. Maftuh, Internalisasi Nilai-Nilai Pancasila dan Nasionalisme Melalui Pendidikan Kewarganegaraan. Jurnal Educationist, 2(2), 2008, hlm. 134-144.

[34] N. Naim. "Pengembangan Pendidikan Aswaja Sebagai Strategi Deradikalisasi." Walisongo: Jurnal 
Penelitian Sosial Keagamaan 23, no. 1 (2015): 6988.

[35] M.S. Haq, Falsafah Bugis untuk Perdamaian Bangsa, online, accessed from https://www.aida.or.id/2021/04/8519/falsafahbugis-untuk-perdamaian-bangsa (2021).
[36] M.S. Muchith, "Radikalisme dalam dunia pendidikan." Addin 10, no. 1 (2016): 163-180.

[37] Orsini, A. (2020). What everybody should know about radicalization and the DRIA model. Studies in Conflict \& Terrorism, 1-33. 